\title{
Note on Transcription and Abbreviations
}

The Wade-Giles transliteration system for Chinese words is used here (and quoted text silently revised in keeping with it) except in the case of names of authors who publish in English and have their own preferred spelling. Unless otherwise noted, all translations are my own.

Works for which a chapter-and-verse or paragraphing reference is generally accepted (e.g., the Analects of Confucius or Plato's dialogues) are noted in that form, and specific editions are cited only when necessary. The following abbreviations are used in the Notes and Bibliography:

BIHP Bulletin of the Institute of History and Philology (Academia Sinica, Nankang, Taiwan)

BMFEA Bulletin of the Museum of Far Eastern Antiquities (Stockholm)

ch. chüan ("volume" of a Chinese book)

CLEAR Chinese Literature: Essays, Articles, Reviews

HJAS Harvard Journal of Asiatic Studies

LH Leibniz mss held in the Niedersächsische Landesbibliothek, Hannover; as catalogued by Eduard Bodemann

Li L L i chi chu-shu (SSCCS ed.)

LSJ Henry G. Liddell, Robert Scott, and Henry S. Jones, $A$ Greek-English Lexicon 
MEGA Karl Marx and Friedrich Engels, Marx-Engels Gesamtausgabe

OED Oxford English Dictionary

Shib Mao Shib chu-shu (SSCCS ed.)

Shu Shang Shu chu-shu (SSCCS ed.)

SKCS Ssu-k'u ch'üan-shu

SPPY Ssu-pu pei-yao

SPTK Ssu-pu ts'ung-k'an

SMSCS Ch'en Huan, ed., Shib Mao shih chuan shu

SSCCS Juan Yüan, ed., Shib-san ching chu-shu

Tso Ch'un-ch'iu Tso chuan chu-shu (SSCCS ed.)

W Hegel, Werke in zwanzig Bänden 
THE PROBLEM OF A CHINESE AESTHETIC 
